\title{
Serological abnormalities in juvenile chronic arthritis: a review of 46 cases
}

\author{
ZSOLT BALOGH, KATALIN MERÉTEY, ANDRÁS FALUS, \\ AND SÁNDOR BOZSÓKY \\ From the National Institute of Rheumatology and Physiotherapy, Budapest, Hungary
}

SUMMARY Data of 46 patients with juvenile chronic arthritis were evaluated. All of them were under the age of 16 at the time of study. Patients with juvenile ankylosing spondylitis, psoriatic arthritis, and arthritis associated with inflammatory bowel disease were excluded from this series. Twenty-six patients had pauciarticular, 9 had systemic, 8 had polyarticular, and 3 patients had seropositive 'adult type' JCA. In all patient groups IgG, IgM, IgA, and C3 levels were significantly higher than in the control group. None of the controls but 13 of 46 patients had high IgE levels. IgA and IgG values were significantly higher in the seropositive subgroup than in the pauciarticular subgroup. There was no other positive correlation between levels of immunoglobulins, C3, and clinical features of disease. Platelet counts were significantly higher in patients with active disease. In the control group 4 out of 10 children had 'hidden' rheumatoid factor. All these children with positive findings were young.

In the latest two decades many papers published from Europe and from America have dealt with the clinical features and immunological characteristics of patients with juvenile chronic arthritis (JCA) (Bianco et al., 1971; Cassidy et al., 1973; Hoyeraal and Mellbye, 1974b; Rudnicki et al., 1974; Schaller and Johnson, 1974; Rossen et al., 1977; Ansell, 1978).

Until recently confusion surrounded the nomenclature and classification of JCA (Ansell and Bywaters, 1959; Ansell and Bywaters, 1962; Grokoest et al., 1962; Grossman et al., 1965; Leaksonen, 1970; Watanabe, 1974; Brewer et al., 1977). The new nomenclature and classification proposed at the EULAR/WHO workshop on the care of rheumatic children in Oslo in 1977 (Ansell, 1978; EULAR, 1978) has now been accepted all over the world. It is now possible to enlarge and complete our knowledge about JCA according to these new criteria and classification, and the purpose of the present paper is to report our data on 46 patients with JCA in the light of this new classification.

We studied some immunological parameters in patients with JCA including serum immunoglobulins (G,M,A,E), rheumatoid factor (RF), 'hidden' RF, antinuclear antibodies (ANA), levels of circulating

Accepted for publication 30 April 1979

Correspondence to $\mathrm{Dr} \mathrm{Z}$. Balogh, Centre for Rheumatic Diseases, Baird Street, Glasgow G4 0EH. immune complexes (IC), HLA B27 antigen, and platelet count, and attempted to correlate these findings with some clinical features.

\section{Materials and methods}

\section{PATIENTS}

Forty-six patients with JCA admitted to hospital in the National Institute of Rheumatology and Physiotherapy, Budapest, between 1973 and 1978 were diagnosed and classified according to the new criteria of the EULAR/WHO workshop, Oslo (Ansell, 1978; EULAR, 1978), and 10 healthy controls matched for age and sex were studied. All the patients were under the age of 16 at the time of study (mean age: $9 \cdot 6$ years, range: $2 \cdot 7-15 \cdot 8$ years). Children known to have juvenile ankylosing spondylitis, psoriatic arthritis, and arthritis associated with inflammatory bowel disease were excluded from this study. Twenty-six of the 46 patients had pauciarticular 9 systemic, 8 polyarticular, and 3 seropositive 'adult type' JCA (Table 1.).

Children were also classified by sex, age, and disease activity. Patients in the first age group were under 4 years old, in the second group 4-8 years old, and in the third group 9-16 years old. Disease activity was evaluated according to a 4 point scale of $0,1,2,3$ on the basis of erythrocyte sedimentation rate (ESR), C-reactive protein (CRP), and clinical 
Table 1 Relation of type of disease to age, sex, and disease activity

\begin{tabular}{|c|c|c|c|c|}
\hline \multirow[t]{2}{*}{ Disease type } & \multirow{2}{*}{$\begin{array}{l}\text { Number of patients } \\
\text { (females/males) }\end{array}$} & \multicolumn{2}{|c|}{ Mean age (range) in years } & \multirow{2}{*}{$\begin{array}{l}\text { Number of patients } \\
\text { with active disease }\end{array}$} \\
\hline & & at onset & at study & \\
\hline Systemic & $\stackrel{9}{9}$ & $\begin{array}{l}4 \cdot 3 \\
(2 \cdot 1-8 \cdot 2)\end{array}$ & $\begin{array}{l}7 \cdot 7 \\
(2 \cdot 7-15 \cdot 8)\end{array}$ & 7 \\
\hline Pauciarticular & $\begin{array}{l}26 \\
(10 / 16)\end{array}$ & $\begin{array}{l}8 \cdot 3 \\
(3 \cdot 2-14 \cdot 3)\end{array}$ & $\begin{array}{l}9 \cdot 9 \\
(3 \cdot 9-15 \cdot 4)\end{array}$ & 8 \\
\hline Polyarticular & $\begin{array}{l}8 \\
8 \\
(6 / 2)\end{array}$ & $\begin{array}{l}7 \cdot 5 \\
(5 \cdot 3-14 \cdot 2)\end{array}$ & $\begin{array}{l}8 \cdot 6 \\
(6 \cdot 2-14 \cdot 9)\end{array}$ & 4 \\
\hline Seropositive 'adult type' & $\begin{array}{l}3 \\
3 \\
(3 / 0)\end{array}$ & $\begin{array}{l}12 \cdot 3 \\
(12 \cdot 0-13 \cdot 0)\end{array}$ & $\begin{array}{l}14 \cdot 3 \\
(12 \cdot 8-15 \cdot 4)\end{array}$ & 1 \\
\hline Total & $\begin{array}{l}46 \\
(22 / 24)\end{array}$ & $\begin{array}{l}7 \cdot 6 \\
(2 \cdot 1-14 \cdot 3)\end{array}$ & $\begin{array}{l}9 \cdot 6 \\
(2 \cdot 7-15 \cdot 8)\end{array}$ & 20 \\
\hline
\end{tabular}

features including swelling, skin temperature, and limitation in movement of joints. Measurement of pain is difficult in juvenile patients and different from its measurement in adults with rheumatoid arthritis (Laaksonen and Laine, 1961; Scott et al., 1977). The articular index (Ritchie et al., 1968) cannot be used because of different numbers of affected joints in different subgroups. Patients with disease activity 0 or 1 were regarded as inactive and with 2 or 3 as active cases.

\section{LABORATORY RESULTS}

Serum IgG, IgM, and IgA levels were measured by Mancini's single radial immunodiffusion method (Mancini et al., 1965) with monospecific IgG (H), $\operatorname{IgM}$ and $\operatorname{IgA}$ rabbit immune sera. $\operatorname{IgE}$ levels were determined by an indirect radial immunodiffusion method (Rowe, 1969) with the Pharmacia IgE kit or IgE PRIST. For the indirect radial immunodiffusion measurement monospecific anti-IgE sheep serum (second antibody) was used. By this method higher than $400 \mathrm{IU} / \mathrm{ml} \mathrm{IgE}$ values could be measured.

C3 levels were determined by Laurell's rocket electrophoresis (Laurell, 1966) with a beta C/ beta $1 \mathrm{~A}$ specific rabbit serum.

For ANA detection the conventional immunofluorescence technique (Holborow and Johnson, 1969) with a fluorescein-labelled anti-IgG $(H+L)$ specific serum was used in 1:20 dilution (Hyland). Sera to be tested were diluted $1: 10$ and $1: 100$ and the strength and pattern of fluorescence evaluated.

For detection of circulating immune complex $3 \%$ polyethylene glycol (PEG) precipitation was used (Creighton et al., 1973) combined both with protein measurements and with determination of IgG, IgM, IgA, C3, and C4 content of IC fractions by means of immune diffusion techniques. Only fresh sera were used. Samples were diluted 1:25 with borate buffer (pH 8.2) and then with $6 \%$ PEG 6000 (Fluka) $1: 2$ to a final dilution of $1: 50$. Tubes were kept at $4^{\circ} \mathrm{C}$ overnight and then washed 3 times in $3 \%$ PEG solution. The precipitates were dissolved in buffered saline (PBS). The protein content was determined by Lowry's method (Lowry et al., 1951). The upper limit of normal was $180 \mathrm{mg} /$ $100 \mathrm{ml}$ (mean of normal donors + $2 \mathrm{SD}$ ).

Rheumatoid factor titres were determined by the latex fixation test and the Waaler-Rose test. For the determination of RFs in immune complex form ('hidden' RFs) the sera were inactivated at $56^{\circ} \mathrm{C}$ for 30 minutes, then diluted 1:4 in PBS and in parallel with $\mathrm{pH} 3.9$ citric acid phosphate buffer. Diluted sera were incubated at $4^{\circ} \mathrm{C}$ for 16 hours and then titrated in microtitre plates for WaalerRose titres. The acidified samples were neutralised in the first wells of plates using $0.4 \mathrm{M} \mathrm{Na} \mathrm{NPO}_{4}$ solution. The increase in titres (at least 2 tubes) of the acidified sample in relation to its control sample (kept at neutrality) was taken as a sign of the presence of complexed ('hidden') rheumatoid factor.

HLA B27 serotyping was performed by the standard NIH microcytotoxicity test (Terasaki et al., 1974).

\section{STATISTICAL ANALYSIS}

The Mann-Whitney $U$ test was used for comparing the measurements of immunoglobulins (G,M,A) and $\mathrm{C} 3$ obtained according to subgroups of disease, age, sex, disease activity and ANA and RF positivity. The chi-squared test was performed when comparing the results for ANA, RF, 'hidden' RF, IC, and high IgE obtained in the various subgroups of disease, age, and activity.

\section{Results*}

\section{IMMUNOGLOBULINS}

The patients' group had significantly higher serum levels of all the immunoglobulins ( $\operatorname{IgG}, \operatorname{IgM}, \operatorname{IgA}$ ) than the control group. In respect of IgG the mean levels were $1131.8 \mathrm{mg} / 100 \mathrm{ml}( \pm \mathrm{SEM} 63.7 \mathrm{mg} /$ $100 \mathrm{ml}$ ) and $807 \mathrm{mg} / 100 \mathrm{ml}( \pm \mathrm{SEM} 90 \cdot 1 \mathrm{mg} / 100 \mathrm{ml})$ in the control group $(\mathrm{P}<0.05)$, while corresponding data for IgM were 151 $6( \pm 5 \cdot 6)$ and 118 $2( \pm 18 \cdot 4)$

*SI conversion: $\mathrm{g} / \mathrm{l}=\mathrm{mg} / 100 \mathrm{ml} \div 100$. 
$(\mathrm{P}<0 \cdot 05)$, of $\operatorname{IgA}$ were $153 \cdot 3( \pm 14 \cdot 1)$ and $95 \cdot 3$ $( \pm 20 \cdot 2)(P<0 \cdot 05)$ (Table 2$)$.

There were significant differences between the oligoarticular and seropositive subgroups in respect of IgG $(1072 \pm 81 \cdot 5$ and $1643 \cdot 3 \pm 286 \cdot 7, \mathrm{P}<0 \cdot 05)$ and of $\operatorname{IgA}(118 \cdot 1 \pm 13 \cdot 2$ and $263 \cdot 6 \pm 60 \cdot 2$, $P<0.05$ ) (Table 3). As regards IgM there were differences, but these did not reach a significant level, as shown in Table 3. One of the patients with oligoarticular disease had selective IgA deficiency.

Analysing the immunoglobulin values of patients in relation to sex, age, disease activity, and RF and ANA positivity, we could not find any statistically significant differences.

Serum concentrations of $\operatorname{IgE}$ in the control group were normal, but 13 of the 46 patients had high levels of IgE. There were no significant differences among the various subgroups.

\section{COMPLEMENT}

C3 levels were significantly higher in the patients than in the controls (mean, $120.6 \mathrm{mg} / 100 \mathrm{ml} \pm \mathrm{SEM}$ $4.4 \mathrm{mg} / 100 \mathrm{ml}$; mean $101 \cdot 1 \mathrm{mg} / 100 \mathrm{ml} \pm \mathrm{SEM}$ $4.5 \mathrm{mg} / 100 \mathrm{ml} ; \mathrm{P}<0.05$ ), but there was no significant difference among the subgroups classified by diagnosis, age, sex, disease activity, or RF and ANA positivity.

\section{A UTOANTIBODIES}

Rheumatoid factors measured by the latex fixation test were detected in 10 out of 46 cases. Apart from the 3 members of the seropositive subgroup this number was 7 out of 43 . Six of the 7 positive patients were in the pauciarticular subgroup ( 5 girls and 1 boy). In the 7 latex-positive cases the positivity varied highly during repeated investigations. All of the 7 Waaler-Rose-positive patients out of the 46 had latex positivity as well at the same time.

'Hidden' RF were found in the sera of 4 out of 10 children in the control group. All 4 children were young (age groups 1 or 2), while 7 out of 8 patients with 'hidden' RF were in the oldest age group (3).

Only 6 out of 46 sera showed ANA positivity either at dilution $1: 10$ or both $1: 10$ and $1: 100$ (5 girls and 1 boy). In the control group no patient was ANA-positive. All our 5 patients with chronic iridocyclitis were classified as pauciarticular JCA ( 4 boys and 1 girl), but none of them had a positive ANA test.

\section{CIRCULATING IMMUNE COMPLEXES}

Thirteen sera of the patient group were tested for immune complexes by the 3\% PEG precipitation method, and only 1 serum had an abnormally high immune complex level. On the other hand sera of 4 out of 10 children from the control group had abnormally high IC levels, and like the 'hidden' RF positivity all the positive cases were classified in the younger age groups ( 1 or 2 ) (Table 4$)$.

\section{PLATELET COUNTING}

This was performed in 20 out of 46 cases. The mean platelet count was $314 \times 10^{9} / 1$. Patients with active disease had significantly higher platelet counts than those with inactive disease (mean $341 \times 10^{9} / 1$ \pm SEM $15 \cdot 2 \times 10^{9} / 1$, and mean $271 \times 10^{9} / 1 \pm \mathrm{SEM}$ $25 \cdot 7 \times 10^{9} / \mathrm{ml}$ respectively; $\mathrm{P}<0 \cdot 05$ ).

\section{Discussion}

In the last few years many authors have reported immunological abnormalities in patients with JCA

Table 2 Relation of serum immunoglobulins and C3 between patients with JCA and age- and sex-matched healthy controls

\begin{tabular}{|c|c|c|c|c|c|}
\hline No. & & $\begin{array}{l}\mathrm{IgG} \\
m g / 100 \mathrm{ml} \\
\text { mean } \pm S E M\end{array}$ & $\begin{array}{l}I g M \\
m g / 100 m l \\
m e a n \pm S E M\end{array}$ & $\begin{array}{l}\mathrm{IgA} \\
m g / 100 \mathrm{ml} \\
m e a n \pm S E M\end{array}$ & $\begin{array}{l}C 3 \\
m g / 100 \mathrm{ml} \\
\text { mean } \pm S E M\end{array}$ \\
\hline $\begin{array}{l}\text { Controls } \\
\text { Patients } \\
\text { P }\end{array}$ & $\begin{array}{l}(10) \\
(46)\end{array}$ & $\begin{array}{l}807 \cdot 0 \pm 90 \cdot 1 \\
1131 \cdot 8 \pm 63 \cdot 7 \\
<0.05\end{array}$ & $\begin{array}{l}118 \cdot 2 \pm 18 \cdot 4 \\
151 \cdot 6 \pm 5 \cdot 6 \\
<0.05\end{array}$ & $\begin{array}{l}95 \cdot 3 \pm 20 \cdot 2 \\
153 \cdot 3 \pm 14 \cdot 1^{*} \\
<0 \cdot 05\end{array}$ & $\begin{array}{l}101 \cdot 1 \pm 4 \cdot 5 \\
120 \cdot 6 \pm 4 \cdot 4 \\
<0.05\end{array}$ \\
\hline
\end{tabular}

*One patient had selective IgA deficiency. SI conversion: $\mathrm{g} / \mathrm{l}=\mathrm{mg} / 100 \mathrm{ml} \div 100$.

Table 3 Relation of serum immunoglobulins and C3 to types of disease

\begin{tabular}{|c|c|c|c|c|}
\hline & $\begin{array}{l}\mathrm{IgG} \\
\mathrm{mg} / 100 \mathrm{ml} \\
\text { mean } \pm S E M\end{array}$ & $\begin{array}{l}\mathrm{IgM} \\
\mathrm{mg} / 100 \mathrm{ml} \\
\text { mean } \pm \text { SEM }\end{array}$ & $\begin{array}{l}I g A \\
m g / 100 m l \\
m e a n \pm S E M\end{array}$ & $\begin{array}{l}C 3 \\
m g / 100 m l \\
m e a n \pm S E M\end{array}$ \\
\hline $\begin{array}{l}\text { Systemic } \\
\text { Pauciarticular } \\
\text { Polyarticular } \\
\text { Seropositive 'adult type' }\end{array}$ & $\begin{array}{l}1114 \cdot 4 \pm 131 \cdot 3 \\
1072 \cdot 0 \pm 81 \cdot 5 \\
1153 \cdot 0 \pm 160 \cdot 7 \\
1643 \cdot 3 \pm 286 \cdot 7\end{array}$ & $\begin{array}{l}170 \cdot 6 \pm 16 \cdot 8 \\
133 \cdot 2 \pm 9 \cdot 5 \\
172 \cdot 5 \pm 29 \cdot 0 \\
199 \cdot 0 \pm 26 \cdot 1\end{array}$ & $\begin{array}{l}197 \cdot 8 \pm 38 \cdot 2 \\
118 \cdot 1 \pm 13 \cdot 2^{*} \\
176 \cdot 2 \pm 38 \cdot 8 \\
263 \cdot 6 \pm 60 \cdot 2\end{array}$ & $\begin{array}{l}125 \cdot 0 \pm 14 \cdot 2 \\
124 \cdot 9 \pm 5 \cdot 0 \\
108 \cdot 2 \pm 3 \cdot 1 \\
103 \cdot 0 \pm 32 \cdot 7\end{array}$ \\
\hline
\end{tabular}

There was significant difference between pauciarticular and seropositive subgroups in relation to $\mathrm{IgG}$ and $\mathrm{IgA}(\mathrm{P}<0.05)$. $\mathrm{SI}$ conversion: $\mathrm{g} / \mathrm{l}=$ $\mathrm{mg} / 1 \div 100$. * One patient had selective IgA deficiency. 
Table 4 Frequency of autoantibodies and high levels of circulating immune complexes in controls and in patients with $J C A$

\begin{tabular}{|c|c|c|c|c|c|c|}
\hline $\begin{array}{l}\text { No. } \\
\text { Controls } 10\end{array}$ & $\begin{array}{l}\text { Latex } \\
0\end{array}$ & $\begin{array}{l}\text { Waaler- } \\
\text { Rose } \\
0\end{array}$ & $\begin{array}{l}\text { 'Hidden' } \\
R F \\
4\end{array}$ & $\begin{array}{l}A N A \\
0\end{array}$ & $\begin{array}{l}I C \\
4\end{array}$ & $\begin{array}{l}\text { (No. tested: } \\
23) \\
(10)\end{array}$ \\
\hline Systemic 9 & 1 & 1 & 2 & 0 & 0 & (2) \\
\hline Pauciarticular 26 & 6 & 3 & 5 & 2 & 1 & (8) \\
\hline $\begin{array}{l}\text { Polyarticular } 8 \\
\text { Seropositive }\end{array}$ & 0 & 0 & 0 & 2 & 0 & (3) \\
\hline 'adult type' 3 & 3 & 3 & 1 & 2 & $\mathbf{0}$ & (0) \\
\hline Total patients 46 & 10 & 7 & 8 & 6 & 1 & (13) \\
\hline
\end{tabular}

Table 5 Relation of platelet count to disease activity in 20 patients with JCA

No. Platelet count/l mean \pm SEM

Patients with active disease $12341 \times 10^{9}+15.2 \times 10^{9}$ Patients with inactive disease $8271 \times 10^{9} \pm 25.7 \times 10^{9}$

$\mathrm{P}<0.05$.

(Houba and Bardfeld, 1969; Bluestone et al., 1970; Bianco et al., 1971; Hoyeraal and Mellbye, 1974a; Hoyeraal and Mellbye, 1974b; Schaller and Johnson, 1974; Rossen et al., 1977). Discrepancies of results reported may be attributable to the various diagnostic criteria and classifications; to the different criteria for evaluation of disease activity, and to differences of immunochemical methodology. Some investigators included adult patients (Houba and Bardfeld, 1969; Bianco et al., 1971).

The present investigation was based on the new diagnostic criteria and classification proposed in Oslo in 1977. Patients with juvenile ankylosing spondylitis, arthritis associated with inflammatory bowel disease, or psoriatic arthritis were excluded from this study. Alterations occur in levels of immunoglobulins during childhood, and immunoglobulin levels are higher in the adult (Stiehm and Fudenberg, 1966; Buckley and Dorsey, 1970). Therefore all our patients were under age of 16 at the time of study. Results were compared to a control group matched for age and sex. All immunoglobulin levels (G,M,A) were significantly higher in the patient group than the control group. There was no significant difference between active and inactive disease groups or between males and females. However, significant differences could be detected between pauciarticular and seropositive subgroups in relation to IgG and IgA. Pauciarticular and systemic subgroups in relation to IgG and IgA, and likewise pauciarticular and seropositive subgroups, differed in relation to $\operatorname{IgM}$, but these differences did not reach the level of significance. Greater numbers of patients would have been better for statistical analysis. As previously noted by Gutowska-
Grzegorczyk (1977, 1978), we have found that some patients with JCA had high levels of IgE without any evidence of disease which might have accounted for this such as allergic diseases, helminthiasis, and so on. There was no relationship between the increased level of IgE and disease activity, age, sex, and subgroups of disease.

As has previously been reported, selective IgA deficiency may occur in JCA with a frequency of $1-4 \%$ (Cassidy and Burt, 1967; Huntley et al., 1967; Pachman et al., 1977). One of our 46 patients had selective IgA deficiency. He was classified as having the pauciarticular type of disease. His mother has rheumatoid arthritis, and determination of her $\operatorname{IgA}$ level is in progress.

The serum complement level in patients with JCA ranged from low to high (Bluestone et al., 1970; Bianco et al., 1971; Goel et al., 1974; Hoyeraal and Mellbye, 1974a). In this study the serum C3 level was significantly higher in patients than in controls, but the difference between active and inactive groups, between males and females, and between different subgroups was not significant.

In contrast to adult rheumatoid arthritis IgMtype RF have been demonstrated in only $12-22 \%$ in sera of patients with JCA (Hanson et al., 1969; Bluestone et al., 1970; Rudnicki et al., 1974; Ansell, 1978). In our survey we have found IgMtype RF in 10 out of 46 patients with positive latex fixation test and 7 out of 46 patients with positive Waaler-Rose test. All the patients with positive Waaler-Rose test had positive latex test simultaneously, and all 3 patients in the seropositive subgroup had both latex and Waaler-Rose positivity on repeated testing. Six of 7 remaining latex-positive cases were classified as pauciarticular ( 5 females and 1 male), and their latex positivity was of no significance at repeated investigations.

Up to $46 \%$ of patients with seronegative JCA may have so-called 'hidden' RF (Moore et al., 1974; Miller et al., 1977). In this study 8 out of 46 patients had 'hidden' RF; most of them (5 out of 8 ) were classified as pauciarticular. There was no direct correlation between 'hidden' RF and disease activity, ANA positivity, or other serological abnormalities. The presence of 'hidden' RF has no diagnostic value, because it can be found in sera of normal children (Bianco et al., 1971; Miller et al., 1977). Our study confirms this statement, because 4 out of 10 control children had 'hidden' RF in their sera. It is of interest that all these control children were under the age of 5 , in contrast to 8 out of 46 patients with 'hidden' RF who were all above the age of 8 . The question remains to be answered of what the influence of age is on this result. Four out of 10 control children had high circulating IC levels in 
their sera, and these children likewise were in youngest age group. Only 1 out of 13 patients had a high level of IC (age 11 years, pauciarticular). While Rossen et al. (1977) reported that high number of patients with systemic JCA had circulating IC in their sera, in this study the 2 patients investigated with systemic disease had no high circulating IC level.

Antinuclear antibodies have been found in 3 to $72 \%$ of sera of patients with JCA (Bluestone et al., 1970; Munthe, 1972; Schaller and Johnson, 1974; Rossen et al., 1972; Permin et al., 1978). In this series $17 \cdot 4 \%$ of patients had positive ANA ( 5 females and 1 male). It is of interest that all our 5 patients with chronic iridocyclitis classified as pauciarticular disease had no ANA. Their sex may be an explanation of this, since 4 were male, and ANA positivity in relationship to chronic iridocyclitis has previously been found mostly in girls with pauciarticular disease (Miller et al., 1966; Rudnicki et al., 1974; Rossen et al., 1977).

The platelet count is positively correlated with disease activity (Endresen et al., 1977). In our 20 cases there were significantly higher platelet counts in patients with active than with inactive disease. Platelet counts at repeated investigations have shown a close parallel with disease activity and seemed to be a good additional measure of disease activity in JCA. However, there are many other causes of high platelet count such as amyloidosis (Endresen et al., 1977) which are not negligible. One of our patients with systemic disease has developed amyloidosis. His platelet count was first $400 \times 10^{9} / 1$, then 2 years later $700 \times 10^{9} / 1$.

In summary, the data reported in this study confirm many other observations on the basic role of the immune system in the pathogenesis of JCA. For a better understanding of the connection between immunological abnormalities and different clinical syndromes and subgroups further study is needed.

The authors thank Allan McLelland (Biochemistry Department, Royal Infirmary, Glasgow) for statistical programming and analysis.

\section{References}

Ansell, B. M. (1978). Chronic arthritis in childhood. Annals of the Rheumatic Diseases, 37, 107-120.

Ansell, B. M., and Bywaters, E. G. L. (1959). Prognosis in Still's disease. Bulletin on Rheumatic Diseases, 9, 189-192.

Ansell, B. M., and Bywaters, E. G. L. (1962). Diagnosis of 'probable' Still's disease and its outcome. Annals of the Rheumatic Diseases, 21, 253-262.

Bianco, N. E., Panush, R. S., Stillman, J. S., and Shur, P. H. (1971). Immunologic studies of juvenile rheumatoid arthritis. Arthritis and Rheumatism, 14, 685-696.

Bluestone, R., Goldberg, L. S., Katz, R. M., Marchesano, J. M., and Calabro, J. J. (1970). Juvenile rheumatoid arthritis: a serologic survey of 200 consecutive patients. Journal of Pediatrics, 77, 98-102.

Brewer, E. J., Bass, J., Baum, J., Cassidy, J. T., Fink, C., Jacobs, J., Hanson, V., Levinson, J. E., Schaller, J., and Stillman, J. (1977). Current proposed revision of JRA criteria. Arthritis and Rheumatism, 20, Supplement 2, 195-199.

Buckley, C. E., 3d., and Dorsey, F. C. (1970). The effect of ageing on human serum immunoglobulin concentrations. Journal of Immunology, 105, 964-972.

Cassidy, J. T., and Burt, A. (1967). Isolated IgA deficiency in juvenile rheumatoid arthritis. Arthritis and Rheumatism, 10, 272-272.

Cassidy, J. T., Petty, R. E., and Sullivan, D. B. (1973). Abnormalities in the distribution of serum immunoglobulin concentrations in juvenile rheumatoid arthritis. Journal of Clinical Investigation, 52, 1931-1936.

Creighton, W. D., Lambert, P. H., and Miescher, P. A. (1973). Detection of antibodies and soluble antigenantibody complexes by precipitation with polyethylene glycol. Journal of Immunology, 111, 1219-1227.

Endresen, G. K., Hoyeraal, H. M., and Kass, E. (1977). Platelet count and disease activity in juvenile rheumatoid arthritis. Scandinavian Journal of Rheumatology, 6, 237240.

EULAR Bulletin, No. 3. (1978). The Care of Rheumatic Children. Pp. 47-50. Edited by E. Munthe. EULAR: Basle.

Goel, M. M., Logan, R. W., Barnard, W. P., and Shanks, R. A. (1974). Serum immunoglobulin and beta 1C/beta 1A globulin concentrations in juvenile rheumatoid arthritis. Annals of the Rheumatic Diseases, 33, 35-38.

Grokoest, A. W., Snyder, A. I., and Schlaeger, R. (1962). Juvenile Rheumatoid Arthritis, pp. 13-16. Little Brown: Boston.

Grossman, B. J., Ozoa, N. F., and Arya, S. C. (1965). Problems in juvenile rheumatoid arthritis. Medical Clinics of North America, 49, 33-47.

Gutowska-Grzegorczyk, G., and Baum, J. (1977). Serum immunoglobulin and complement interrelationships in juvenile rheumatoid arthritis. Journal of Rheumatology, 4, 179-185.

Gutowska-Grzegorczyk, G., and Baum, J. (1978). in EULAR Bulletin No. 3. The Care of Rheumatic Children, pp. 3535. Edited by E. Munthe. EULAR: Basle.

Hanson, V., Drexler, E., and Kornreich, H. (1969). The relationship of rheumatic factor to age of onset in juvenile rheumatoid arthritis. Arthritis and Rheumatism, 12, 8286.

Holborow, E. J., and Johnson, G. D. (1969). The immunofluorescent test for serum antinuclear factor. Association of Clinical Pathologists Broadsheet, March, 65,

Houba, V., and Bardfield, R. (1969). Serum immunoglobulins in juvenile rheumatoid arthritis. Annals of the Rheumatic Diseases, 28, 55-57.

Hoyeraal, H. M., and Mellbye, O. J. (1974a). High levels in serum complement factors in juvenile rheumatoid arthritis. Annals of the Rheumatic Diseases, 33, 243-247.

Hoyeraal, H. M., and Mellbye, O. J. (1974b). Humoral immunity in juvenile rheumatoid arthritis. Annals of the Rheumatic Diseases, 33, 248-254.

Huntley, C. C., Thorpe, D. P., Lyerly, A. D., and Kelsey, W. M. (1967). Rheumatoid arthritis with IgA deficiency. American Journal of Diseases of Children, 113, 411-418.

Laaksonen, A. L., and Laine, V. (1961). A comparative study of joint pain in adult and juvenile rheumatoid arthritis. Annals of the Rheumatic Diseases, 20, 386-387.

Laaksonen, A. L. (1970). Diagnostic criteria for juvenile rheumatoid arthritis. Duodecim, 86, 333-339.

Laurell, C. B. (1966). Quantitative estimation of proteins 
by electrophoresis in agarose gel containing antibodies. Analytical Biochemistry, 13, 45-52.

Lowry, O. H., Rosenbrough, N. J., Farr, A. L., and Randall, R. J. (1951). Protein measurement with the Folin phenol reagent. Journal of Biological Chemistry, 193, 265-268.

Mancini, G., Carbonara, A. O., and Heremans, J. F. (1965). Immunochemical quantitation of antigen by single radial immunodiffusion. International Journal of Immunochemis$\operatorname{try}, 2,235-254$.

Miller, J. J., Henrich, V. L., and Brandstrup, N. E. (1966). Sex difference in incidence of antinuclear factors in juvenile rheumatoid arthritis. Pediatrics, 38, 916-918.

Miller, J. J., Olds-Arroyo, L., and Akasaka, T. (1977) Antiglobulins in juvenile rheumatoid arthritis. Arthritis and Rheumatism, 20, 729-735.

Moore, T., Dorner, R. W., Zuckner, J. (1974). Hidden rheumatoid factor in seronegative juvenile rheumatoid arthritis. Annals of the Rheumatic Diseases, 33, 255-257.

Munthe, E. (1972). Anti IgG and antinuclear antibodies in juvenile rheumatoid arthritis. Scandinavian Journal of Rheumatology, 1, 161-170.

Pachman, L. M., Hafeman, C., and Jawor, D. (1977). IgA deficiency and juvenile rheumatoid arthritis. Arthritis and Rheumatism, 20, Supplement 2, 445-448.

Permin, H., Horbov, B., Wiik, A., and Knudsen, J. V. (1978). Antinuclear antibodies in juvenile chronic arthritis. Acta Pediatrica Scandinavica, 67, 181-185.

Ritchie, D. M., Boyle, J. A., McInnes, J. M., Jasani, M. K., Dalakos, T. G., Grieveson, P., and Buchanan, W. W. (1968). Clinical studies with an articular index for the assessment of joint tenderness in patients with rheumatoid arthritis. Quarterly Journal of Medicine, 37, 393-406.
Rossen, R. D., Brewer, E. J., Person, D. A., Templeton, J. W., and Lidsky, M. D. (1977). Circulating immune complexes and antinuclear antibodies in juvenile rheumatoid arthritis. Arthritis and Rheumatism, 20, 1485-1490.

Rowe, D. S. (1969). Radioactive single radial diffusion. A method for increasing the sensitivity of immunochemical quantification of proteins in agar gel. Bulletin of the World Health Organisation, 40, 613-616.

Rudnicki, R. D., Ruderman, M., Scull, E., Goldenberg, A. and Rothfield, N. (1974). Clinical features and serologic abnormalities in juvenile rheumatoid arthritis. Arthritis and Rheumatism, 17, 1007-1015.

Schaller, J. G., and Johnson, G. D. (1974). The association of antinuclear antibodies with chronic iridocyclitis of juvenile rheumatoid arthritis (Still's disease). Arthritis and Rheumatism, 17, 409-416.

Scott, P. J., Ansell, B. M., and Huskisson, B. C. (1977). Measurement of pain in juvenile chronic polyarthritis. Annals of the Rheumatic Diseases, 36, 186-187.

Stiehm, E. R., and Fudenberg, H. H. (1966). Serum levels of immune globulins in health and disease: a survey. Pediatrics, 37, 715-727.

Terasaki, P., McClelland, J. D., Park, M. S., and McCurdy, B. (1974). Microdroplet lymphocyte cytotoxicity test. In Ray, J. G., Hare, D. B., Pedersen, P. D., and Kayhoe, D. E. (Editors), Manual of Tissue Typing Techniques, pp. 34-61. DHEW Publ. (NIH): Government Printing Office, Washington.

Watanabe, N. (1974). Criteria for the classification of juvenile rheumatoid arthritis. Ryumachi, 14, 59-62. 